\title{
Development of the Discovery With Team Assisted Individualization (D- TAI) Model to Empower Analytical Thinking Ability in the Material Human Reproductive System
}

\author{
Aulia Novitasari ${ }^{1}$, Sutarno $^{2}$, dan Mohammad Masykuri ${ }^{3}$ \\ 11 Universitas Islam Negeri Raden Intan Lampung \\ 2Universitas Sebelas Maret Surakarta \\ Coressponding Author. E-mail: \\ 1aulianovitasari@radenintan.ac.id \\ nnsutarno@staff.uns.ac.id \\ 3mmasykuri@staff.uns.ac.id
}

Received: April 18 ${ }^{\text {th }}, 2020$

Accepted: July 26st, 2020

Online Published: July $27^{\text {th }}, 2020$

\begin{abstract}
The objectives of this research and development are: to find out the characteristics of the Discovery with Team Assisted Individualization (D-TAI) learning model, determine the feasibility of the D-TAI learning model, and test the effectiveness of the product model in empowering analytical thinking skills. Model development research refers to Borg \& Gall, which was adapted into nine stages: research and data collection, planning, initial product development, initial testing, product revision I, main field revision, product revision II, operational field revision, and final product revision. Analysis of the data used is a qualitative and quantitative descriptive analysis using the Mann Whitney $U$ test. The results of the research and development show: the development of the D-TAI model was carried out with regard to the characteristics of the model. the results of the development of the D-TAI model are applied to the material of the human reproductive system. D-TAI model is able to empower students' analytical thinking skills. The results of the study show a significant difference between the value of analytical thinking skills in the D-TAI model class and the control class that is the average value of the D-TAI model class (74.79) higher than the control class ( 55.91) control with sig level $0.00<0.05$.
\end{abstract}

Keywords: Discovery; TAI; D-TAI Model; Thinking Analysis

How to cite this article :

Novitasari, A., Sutarno, S., \& Masykuri, M. (2020). Development of the Discovery With Team Assisted Individualization (D-TAI) Model to Empower Analytical Thinking Ability in the Material Human Reproductive System. IJIS Edu : Indonesian Journal of Integrated Science Education, 2(2), 119-130. doi:http://dx.doi.org/10.29300/ijisedu.v2i2.3088 


\section{INTRODUCTION}

21st Century education requires students to have the ability to think as a form of success from learning, namely learning to understand knowledge, learning to do something, learning to live socially, and learning to explore the potential (UNESCO, 2013). The ability to think is a capability that is very important because it affects the success of an individual. Higher-order thinking skills(Listyani, 2011) is an ability that is essential for life and affects the success of life because it involves what is done and also what is produced by the individual, therefore the ability to think has an important role in developing attitudes and perceptions that support the creation of positive classroom conditions, obtain, and integrate knowledge broadening knowledge horizons, actualizing the meaningfulness of knowledge and developing beneficial thinking behavior. The ability to think level can be improved, one of them through the analysis. The ability to think analysis is the ability to think students to describe, and analyze information used to understand a knowledge by using logical reasoning and mind, not based on mere feelings or guesses (Montaku, 2011). The ability to think analytically is the skill of breaking down a structure into components in order to know the organization of structures.

The analytical thinking ability proposed by Elder \& Paul (2007) consists of eight components namely; (1) raising questions relating to problems, (2) formulating objectives, (3) using information in the form of data, facts, observations, experiments, (4) making assumptions, (5) using concepts, (6) implying, (7) use other information / discourse, (8) make conclusions. Analytical thinking skills have a very important role in helping to make decisions, solve problems, analyze, and assess situations by subjecting a situation, subject matter or decision to a rigorous examination and logical step by step, testing statements or evidence or proposals in front objective standards, dipping below the surface to the root of the problem, and weighing and deciding on the basis of logic (Rose \& Nicholl, 2002).

Analytical thinking ability is one of the factors that determine learning success. Students who have high analytical skills, are more skilled, more active, and creative in solving problems, and have high curiosity (Mahmudah, 2014). The ability to think analytically influences the formation of students' conceptual systems, so students are able to easily gain understanding, long-term memory, and find ideas to solve problems (Jonassen, 2008). Therefore, analytical thinking ability is important to be empowered. Analytical thinking skills can be trained through student learning processes (Silberman, 2001). but the reality that is often found in schools of students' analytical thinking ability is relatively low.

The results of the pre-research conducted related to the 8 National Education Standards (SNP) at Public Senior High School 8 Surakarta obtained a gap in the process standard that is equal to $4.17 \%$, which shows that the lack of fulfillment of process standards that have an impact on student learning outcomes, this is supported based on test results students' low analytical thinking skills are 38, 35\%.

Learning is still teacher centered, $45.83 \%$ of students are accustomed to learning using the lecture learning model varies by the teacher $58.33 \%$ of students still consider biology as rote learning, $62.50 \%$ of students consider the learning model used by the teacher less attractive, and $58.33 \%$ of students are not accustomed to being trained in higher-order thinking skills. Students are less actively involved in the learning process, students just sit still, listen to the teacher's explanation, take notes on the subject matter. The learning process that facilitates students to construct their own knowledge and develop the ability to think through scientific methods and attitudes is not very empowered, so students consider biology as a difficult subject, many memorized, less interesting, and boring. Data on the 2013/2014 national exam results show that the percentage of mastery of material related to the basic competencies of the reproductive system in humans is still low at $31.00 \%$ at the school level, $56.47 \%$ at the district level, $39.01 \%$ at the provincial level and $43,18 \%$ at the national level (BSNP, 2013). The low percentage of mastery of the material shows that indicators are still not fulfilled the objectives of learning.

The solution made to overcome the problem of not fulfilling indicators - indicators of learning objectives including indicators of students 'analytical thinking skills is to choose a learning model that is student centered, able to construct knowledge, and empower students' analytical thinking skills, one of which is the learning model of Ciscovery. Discovery learning model is a learning model that allows students to develop active learning ways by finding their own 
knowledge, so that students are able to explore the ability to think analytically and try to solve their own problems through scientific methods and attitudes (Husain, 2013). Discovery learning model has five learning syntax, namely: stimulation, problem statement, data collecting, data processing, verification, and generalization (Divine, 2012).

Discovery learning model has a weakness that is less effective in its implementation, because not all students are able to make discoveries, as written by the Ministry of Education and Culture (2013) that the discovery model was developed based on the assumption that students already have a readiness of thought in learning. the relationship between concepts, whether written or oral so that it can cause frustration. The weaknesses of the discovery learning process can be overcome by combining them with other appropriate learning elements. One alternative learning model that can be integrated with cooperative learning models. Team Assisted Individualization (TAI) is one of the cooperative learning models designed to overcome individual student learning difficulties, bearing in mind the ability of students in the class to vary (Jannah, 2009). This type of TAI cooperative learning model was developed based on the thought that students enter the classroom with very diverse knowledge, abilities, and motivations. When teachers submit a learning material to each group, it is likely that there are some students who do not have the ability to learn it will fail (Slavin, 2009). One characteristic of the TAI model is the importance of mutual learning and learning through discussion activities. Scoring and giving awards to groups makes students aware of their personal responsibilities, because students realize that their group peers want to achieve success as proof of their social status in the classroom.

The TAI learning model is also able to overcome time allocation problems (Slavin, 2009). The allocation of time required is not too much, because the teacher does not guide one by one student but through peer tutoring activities. Students who are less clever will learn with the help of a groupmate who has higher academic abilities, and vice versa group members with high academic abilities through tutorial activities on low-ability students, will make their understanding of the concept better, so that their learning achievement will increase, but the TAI learning model has a weakness that is less empowering the characteristics of biology as science. In this context, it is necessary to integrate discovery learning models with TAI which can complement each other into discovery learning models - team assisted individualization (D-TAI).

The integration of discovery learning models with TAI into D-TAI learning models aims to create learning that gives rise to cognitive conflictstudents not only work in the realm of low thinking but are already referring to analytical thinking. Students are able to empower the characteristics of science that produce products through scientific processes and methods that are based on scientific attitudes so that students are able to construct their own knowledge and be able to learn and learn through cooperative activities that hopefully can change the paradigm from teacher centered to student centered. So, this model development research aims: (1) developing the D-TAI learning model, (2) testing the feasibility of the D-TAI model, and (3) testing the effectiveness of the D-TAI model to empower students' analytical thinking skills

\section{RESEARCH METHOD}

This research is a Research and Development study. The product development and validation stage is carried out at Sebelas Maret University. The location of the product field trial is at Public Senior High School 8 Surakarta. The school is located on Jl. Sumbing VI / 49, Mojosongo Village, Jebres Subdistrict, Surakarta City. This research was conducted on April 20, 2015 at Public Senior High School 8 Surakarta.

Research on the development of the DTAI learning model refers to Borg and Gall (1983) which have been adapted to become multilevel, namely: (1) research and data collection, (2) planning, (3) initial product development, (4) initial trials, ( 5) product revision (6) main field test, (7) product revision II, (8) operational field test, and (9) product revision III.

The research phase and data collection in this study is the needs analysis. Activities carried out in this stage include analysis of the 8 National Education Standards (SNP) evaluating the results of the National Examination (UN), analysis of students' analytical thinking skills, interviews with teachers and students, learning observations and analysis of the Learning Implementation Plan (RPP) and their implementation.

The planning stage is done by designing the D-TAI learning model. Planning includes the 
achievement of competencies, the formulation of objectives, learning sequences, and learning instruments, in addition to this planning stage is also used to determine the qualifications of those who will be involved in research development and validators including material experts, model development experts, learning practitioners and students.

The initial product development began with the development of the syntax of the D-TAI learning model, namely by integrating the Discovery model with the TAI model. The development of the learning model includes six components proposed by Joyce \& Calhoun (2004), namely (1) theoretical foundation, (2) social systems, (3) learning syntax, (4) teacher roles and tasks; (5) support systems, and (6) instructional \& accompaniment impacts

The D-TAI model prototype is equipped with a set of tools including: RPP according to the 2013 curriculum syllabus, student workbooks, teacher manuals, and evaluation instruments. The design of learning tools is adapted to the format that applies to the 2013 curriculum. Initial field trials were conducted to obtain initial qualitative evaluations of the draft products that have been made. The initial trial was conducted with an expert validation test consisting of a validation of biology material experts and a validation of learning model development experts. The test results were analyzed descriptively namely qualitative and quantitative descriptive using the revised decision in Table 1.

Table 1. Revision Decision Making

\begin{tabular}{ccc}
\hline $\begin{array}{c}\text { Level of } \\
\text { Achievement } \\
\mathbf{( \% )}\end{array}$ & Qualification & Remarks \\
\hline $\mathbf{9 0 - 1 0 0}$ & Very Good & Not Revised \\
$\mathbf{7 5}-\mathbf{8 9}$ & Well & Not Revised \\
$\mathbf{6 5}-\mathbf{7 4}$ & Enough & Revised \\
$\mathbf{5 5}-\mathbf{6 4}$ & Not Good & Revised \\
$\mathbf{0}-\mathbf{5 4}$ & Very Less & Revised \\
\hline
\end{tabular}

Source: Fatmawati, 2013

Product revision I was carried out based on the results of the expert validation test of the development of the D-TAI learning model and material, so that it was given consideration material to improve the initial product regarding the D-TAI learning model.

The main field test phase was carried out by 2 education practitioners and 10 students to get an assessment and suggestions for improvement. Retrieval of data using validation sheets and questionnaires. The test results were analyzed descriptively namely qualitative and quantitative descriptive (percentage techniques) using the revised decision as in Table 1.

The second product revision phase is based on suggestions for improvement from educational practitioners and students as product users in the field. The second product revision aims to improve the D-TAI learning model to make it more feasible to be applied in operational field tests.

The operational field test phase was carried out at Public Senior High School 8 Surakarta with a quasi-experimental setting using the pretest - posttest design. The research sample was determined by purposive sampling in $11^{\text {th }}$ grade MIA 3 and 4 . The test results consisted of syntax, teacher responsiveness and student performance data and students' analytical thinking skills obtained through questionnaire observation sheets and tests. Data analysis was performed descriptively with qualitative and quantitative analysis of the value of thinking thinking skills using the Mann Whitney $\mathrm{U}$ test with the help of the SPSS 21 program.

Phase III product revisions are carried out based on operational field test results. Qualitative information and analysis results are used as a basis for revising the product of the learning model in order to obtain a model that is feasible to apply in the field)

\section{RESULTS AND DISCUSSION}

The initial stage of development research undertaken is a needs analysis which includes: analysis of 8 National Education Standards, interviews with teachers and students, analysis of learning observations, analysis of students' analytical thinking skills, and analysis of UN results related to the absorption of biological material.

The results of observations of 8 National Education Standards in Surakarta 8 Public High School showed a fairly high gap in the standard process of $4.17 \%$, this indicates that the lack of fulfillment of process standards that have an impact on the results

student learning. The results of interviews with biology teachers stated that the model of learning that is often used is varied lectures. Teachers have difficulty in choosing the right learning model, especially on abstract material. 
Data on the results of analysis of the national examination of Public Senior High School 8 Surakarta in the academic year $2013 / 2014$ shows the percentage of mastery of the material related to the basic competencies of the human reproductive system is still low. The results of the analysis show that the students' thinking ability of analysis is low at $38.35 \%$, this indicates that the indicators of thinking analysis of students have not been fulfilled.

The results of the needs analysis showed that the majority of students in the amount of $58.33 \%$ of students still considered that biology was rote learning, $45.83 \%$ of students accustomed to learning by using lecture learning models varied by teachers, $62.50 \%$ of students considered the model used by teachers less interesting, $58.33 \%$ of students are not accustomed to being trained in high-level thinking skills, $75 \%$ of students have never been taught to use a team-assisted individual modelzation and $62,50 \%$ of students stated that they had never been taught using discovery learning models.

Based on the results of field studies andliterature study obtained a solution to the development of learning models that are discovery and cooperative. Model development is carried out specifically on the competence of the human reproductive system which is supported by the development of all its devices and instruments, in the form of developing a prototype of the D-TAI Learning Implementation Plan (RPP) model in accordance with the characteristics of the 2013 curriculum, developing workbooks, evaluation instruments, research instruments.

Table 2. Results of the Development of D-TAI Learning Model Components

\begin{tabular}{|c|c|}
\hline $\begin{array}{c}\text { Component } \\
\text { Model }\end{array}$ & Explanation \\
\hline $\begin{array}{l}\text { Base } \\
\text { Theory }\end{array}$ & $\begin{array}{l}\text { D-TAI learning is developed } \\
\text { based on the needs analysis } \\
\text { han need for standard } \\
\text { improvementprocess on repro } \\
\text { system materialhuman duction at } \\
\text { Public Senior High School } 8 \\
\text { Surakarta. While the theory } \\
\text { underlying the D-TAI learning } \\
\text { model includes: David Ausebel's } \\
\text { learning theory, Jerome Bruner's } \\
\text { discovery, John Dewey's problem } \\
\text { solving, Piaget's intellectual }\end{array}$ \\
\hline
\end{tabular}

\begin{tabular}{|c|c|}
\hline & $\begin{array}{l}\text { development, Humanistic views, } \\
\text { and Constructivism. }\end{array}$ \\
\hline $\begin{array}{l}\text { Learning } \\
\text { Syntax }\end{array}$ & $\begin{array}{l}\text { The syntax of learning developed } \\
\text { development is an integration of } \\
\text { discovery learning model and TAI } \\
\text { produces } 10 \text { stages, that is } \\
\text { placement test, teams, stimulation } \\
\text { with curriculum material, problem } \\
\text { statement with team study, data } \\
\text { collecting with teachin group, data } \\
\text { processing, verification with whole } \\
\text { class units, generalization, team score } \\
\text { \& team recognition, dan fact test. }\end{array}$ \\
\hline $\begin{array}{l}\text { Social } \\
\text { system }\end{array}$ & $\begin{array}{l}\text { D-TAI learning model can lead to } \\
\text { social systems in the classroom. } \\
\text { Group activities in the D-TAI } \\
\text { syntax stimulate students to } \\
\text { exchange ideas in discussion } \\
\text { activities, exchange ideas, and } \\
\text { correct each other's mistakes } \\
\text { among group members, as well as } \\
\text { learn from one another and learn } \\
\text { in constructing and finding } \\
\text { concepts in learning activities. }\end{array}$ \\
\hline $\begin{array}{c}\text { Teacher's } \\
\text { Roles and } \\
\text { Duties }\end{array}$ & $\begin{array}{l}\text { The role and task of the teacher in } \\
\text { the DTAI model is not only to } \\
\text { become a teacher, but also } \\
\text { provide training related to the } \\
\text { mentality of students, motivators, } \\
\text { facilitators, questioners, } \\
\text { administrators, directors, } \\
\text { managers, and rewarders. }\end{array}$ \\
\hline $\begin{array}{l}\text { Supporting } \\
\text { System }\end{array}$ & $\begin{array}{l}\text { The D-TAI learning model can } \\
\text { run smoothly if it is supported by } \\
\text { syllabus, lesson plans, teacher } \\
\text { manuals, student manuals, } \\
\text { assessments, and learning } \\
\text { facilities.In addition, it is also } \\
\text { supported by teacher } \\
\text { competence. }\end{array}$ \\
\hline $\begin{array}{c}\text { Instructiona } \\
1 \text { Impact } \\
\text { and } \\
\text { Accompani } \\
\text { ment } \\
\text { Impact }\end{array}$ & $\begin{array}{l}\text { The instructional impact of the } \\
\text { D-TAI learning model includes } \\
\text { the potential of the model in } \\
\text { improving thinkingstudent } \\
\text { analysis, which is followed by the } \\
\text { accompanying impact of mening } \\
\text { increase learning motivation } \\
\text { andminimize the gap between sis } \\
\text { wa high academic ability and } \\
\text { capable students low. }\end{array}$ \\
\hline
\end{tabular}

The initial procedure for developing the D-TAI model begins with the preparation of a model prototype that contains six conceptual 
components of the learning model. The results of the development can be seen in Table 2 .

The syntax of the D-TAI learning model can be described as follows:

\section{Placementt Test}

This syntax is an activity to find out students' initial knowledge. At this stage the teacher gives a test in the form of questions to students as a step to determine the readiness of learning or the initial conditions of students. Learning theory: David Ausebel.

\section{Teams}

The team or group stage is the teacher's activity dividing students into four to five heterogeneous groups. This syntax was developed based on Vygotsky's Sociocultural learning theory, namely learning success is achieved because of social interaction.

\section{Stimulation with Curriculum Material}

This syntax is an activity to increase student interest in learning material that is preceded by the distribution of student workbooks by the teacher. At this stage the teacher exposes students to something that attracts students' attention and causes confusion. The teacher asks students to read articles that contain problems (Slameto, 2003). Learning theory: Humanistic.

\section{Problem Statement with Team Study}

This syntax is a stage of the D-TAI model that stimulates students to ask questions questions related to stimulation provided by the teacher as a group. The teacher provides opportunities for students to identify as many problems - issues that are relevant to teaching materials in groups,

Then choose it and can submit temporary answers in the form of hypotheses related to learning material. At this stage the teacher is tasked with directing students to formulate problems related to learning goals (Trianto, 2007). The learning theory of John Dewey and Sociocultural Vygotsky.

\section{Data Collecting with Teaching Group}

This syntax is an activity to gather and collect information in groups needed to test the hypothesis proposed with the guidance of the teacher. At this stage students are given the opportunity to collect various relevant information, read literature, observe objects, interview with resource persons, conduct their own trials and so on. Theories of learning Jerome Bruner and Sociocultural Vygotsky.

\section{Data Processing}

Data processing is an activity to process data and information. At this stage students conduct collaborative discussions with group friends to solve problems. Learning theory: Constructivists, Jerome Bruner's Invention, Piaget's intellectual development, Sociocultural Vygotzky.

\section{Verification with Whole-Class Units}

This syntax is the student's activity in proving, correcting, and justifying the results obtained through presentation activities in front of the class and then the teacher provides justification through classical teaching of erroneous or wrong concepts (Siregar \& Nara, 2010). Learning theory: Vygotsky's Humanistic and Sociocultural.

\section{Generalization}

This crossing is a student activity in drawing conclusions based on learning outcomes (Trianto, 2007). The constructivist learning theory and John Dewey.

\section{Team Score \& Team Recognition}

This syntax is an activity of scoring and awarding the best group. This activity aims to motivate students to study harder. The calculation of team scores by teachers is based on the average number of results obtained by students' workbook grades and the percentage of each team member (Schunk, 2012). Learning Theory: Sociocultural Vygotsky.

\section{Fact Test}

The fact test stage is an indicator achievement test. At this stage the teacher gives a test in the form of questions to students to find out the achievement of learning indicators (Dahar, 2009). Learning theory: David Ausebel A 
prototype of a ready-made learning model will be complemented by the development of learning tools that support the implementation of the model, including: Learning Implementation Plan (RPP) in accordance with the 2013 curriculum syllabus, student workbooks, teacher's manuals, and evaluation instruments. The design of learning devices is adapted to the characteristics of the D-TAI model and the applicable formatdeveloped the 2013 curriculum. The results of the development of the model development then went through the revision and validation stages by experts with the results can be seen in Table 2 and Table 3.

The results of the validation by the material experts got a very good category, while the validation of the device experts got a good category. The stages are followed by a clasll group assessment of users (education practitioners and students) with the results of the assessment summarized in Table 4 and Table 5.

The results of the validation of the expert practitioners obtained an assessment with excellent categories and students with good categories so that the model development stage was feasible to proceed to the operational field trial phase. Field tests were carried out on $11^{\text {th }}$ grade MIA 3 as a control class and $11^{\text {th }}$ grade MIA 4 as a class treated with the D-TAI model. The results of the syntax implementation in the treatment class can be seen in Table 6

Table 3. Product Validation by Device Experts

\begin{tabular}{lcc}
\hline Aspect Of Rating & $\begin{array}{c}\text { Persentage } \\
\mathbf{( \% )}\end{array}$ & Category \\
\hline $\begin{array}{l}\text { Learning Model } \\
\text { Learning }\end{array}$ & 79,17 & Good \\
$\begin{array}{l}\text { Implemetation } \\
\text { Plan }\end{array}$ & 84,04 & Good \\
$\begin{array}{l}\text { Students } \\
\text { Workbook }\end{array}$ & 83,33 & Good \\
$\begin{array}{l}\text { Assessment } \\
\text { Research } \\
\text { Instruments }\end{array}$ & 80,00 & Good \\
\hline Average & 75,00 & Good \\
\hline
\end{tabular}

Table 4. Product Validation by Material Expert

\begin{tabular}{ccc}
\hline $\begin{array}{c}\text { Aspect Of } \\
\text { Rating }\end{array}$ & $\begin{array}{c}\text { Persentage } \\
\mathbf{( \% )}\end{array}$ & Category \\
\hline $\begin{array}{c}\text { Material } \\
\text { Suitability }\end{array}$ & 91,67 & Very Good \\
$\begin{array}{c}\text { Material Format } \\
\text { Material }\end{array}$ & 87,50 & Good \\
Coverage & 93,75 & Very Good \\
Accuracy & 100 & Very Good \\
$\begin{array}{c}\text { Update } \\
\text { Persentation of } \\
\text { Material } \\
\text { Display }\end{array}$ & 91,67 & Very Good \\
\hline Average & 100 & Very Good \\
\hline
\end{tabular}

Table 5. Product Validation by Practitioner Experts

\begin{tabular}{ccl}
\hline Aspect Of Rating & $\begin{array}{c}\text { Persentage } \\
\mathbf{( \% )}\end{array}$ & Category \\
\hline $\begin{array}{c}\text { Learning Model } \\
\text { Learning }\end{array}$ & 93,75 & Very Good \\
$\begin{array}{c}\text { Implemetation } \\
\text { Plan }\end{array}$ & 100 & Very Good \\
$\begin{array}{c}\text { Students } \\
\text { Workbook }\end{array}$ & 90,28 & Very Good \\
Assessment & 86,36 & Good \\
$\begin{array}{c}\text { Research } \\
\text { Instrument } \\
\text { Theory }\end{array}$ & 95,84 & Very Good \\
\hline Average & 94,05 & Very Good \\
\hline
\end{tabular}

Table 6. Product Validation by Students

\begin{tabular}{ccc|}
\hline $\begin{array}{c}\text { Aspect Of } \\
\text { Rating }\end{array}$ & Persentage (\%) & Category \\
\hline Content & 86,25 & Good \\
Digestion & 94,17 & Very Good \\
Use of Language & 92,50 & Very Good \\
\hline Display & 85,00 & Good \\
\hline Average & 89,48 & Good \\
\hline
\end{tabular}

Table 7. Percentage of Syntability

\begin{tabular}{ccc}
\hline Aspect Of & \multicolumn{2}{c}{ Percentage of Workability (\%) } \\
\cline { 2 - 3 } Rating & Teacher & Student \\
\hline $\mathbf{1}$ & 81,25 & 87,50 \\
$\mathbf{2}$ & 87,50 & 87,50 \\
$\mathbf{3}$ & 100 & 93,75 \\
$\mathbf{4}$ & 100 & 100 \\
\hline
\end{tabular}


The results of the implementation of the syntax at the first, second, third, and fourth meeting showed a very good category, this can be interpreted that the teacher and students were able to implement the steps of the D-TAI model well. The results of the analysis of students' pretest scores showed that both classes had the same analytical thinking ability, namely 24.5 in the experimental class and 23.4 in the control class, then the two classes were given different treatments, namely the D-TAI learning model in $11^{\text {th }}$ grade MIA 4 and the method lectures vary in $11^{\text {th }}$ grade MIA 3 as a control which is then given a posttest at the end of learning to determine the effectiveness of using the D-TAI learning model.

Based on the results of the analysis of Mann Whitney $U$ test data calculations in Table 7 shows a significant difference in the value of students' analytical thinking skills in the D-TAI model and control class (sig $0.00<0.05$ ). The average value of the students' analytical thinking ability test in the D-TAI model class is higher than the control class that uses the varied lecture method. The mean obtained in the D-TAI model class was 74.79 with KKM completeness of $95.83 \%$ and 55.91 in the control class with completeness

$\mathrm{KKM}$ of $12.50 \%$, the data is strengthened by Gain analysis obtained probability of $0.00<0.05$, then $\mathrm{H} 0$ is rejected, meaning that the D-TAI model class gain is higher than the varied lecture classes. Based on the results of research that has been done, it is known that the D-TAI learning model can improve students' analytical thinking skills. The high analytical thinking ability of students in the D-TAI model class is because students are actively involved in learning, besides, the activities carried out during the learning process are dynamic, interesting, and easy to understand. Students are required not only to sit still, take notes, listen to the teacher's explanation, but learn through direct experience so that understanding will last longer in memory. The D-TAI learning model supports the intellectual development of students related to the ability to draw conclusions based on the experience gained.
Table 8. Analysis Thinking Ability Analysis

\begin{tabular}{|c|c|c|}
\hline Testing & Sig & Conclusion \\
\hline \multicolumn{3}{|l|}{ Pretest } \\
\hline Normality & $\begin{array}{l}\text { Sig. Model D- } \\
\text { TAI = } 0,04 \\
\text { Sig. Control = } \\
0,00\end{array}$ & $\begin{array}{l}\text { Normal } \\
\text { Distribution }\end{array}$ \\
\hline Comparison & $\operatorname{Sig}=0,63$ & $\begin{array}{l}\text { No } \\
\text { Significant } \\
\text { Difference }\end{array}$ \\
\hline \multicolumn{3}{|l|}{ Postest } \\
\hline Normality & $\begin{array}{l}\text { Sig.D-TAI = } \\
0,00 \\
\text { Sig.Control }= \\
0,03\end{array}$ & $\begin{array}{l}\text { No } \\
\text { Normality } \\
\text { Distributed }\end{array}$ \\
\hline Comparison & Sig $=0,00$ & $\begin{array}{l}\text { Significantly } \\
\text { Different }\end{array}$ \\
\hline \multicolumn{3}{|l|}{ Gain } \\
\hline Normality & $\begin{array}{l}\text { Sig. D-TAI = } \\
0,20 \\
\text { Sig.control }= \\
0,20\end{array}$ & $\begin{array}{l}\text { Normal } \\
\text { Distribution }\end{array}$ \\
\hline $\begin{array}{l}\text { Homogeneit } \\
\text { y }\end{array}$ & Sig $=0,33$ & $\begin{array}{l}\text { Variants of } \\
\text { both samples } \\
\text { are the same }\end{array}$ \\
\hline $\begin{array}{l}\text { Test the } \\
\text { similarity of } \\
\text { two averages }\end{array}$ & Sig $=0,00$ & $\begin{array}{l}\text { The gain of } \\
\text { the two } \\
\text { classes is } \\
\text { significantly } \\
\text { different }\end{array}$ \\
\hline $\begin{array}{l}\text { Two-average } \\
\text { comparison } \\
\text { test }\end{array}$ & Sig $=0,00$ & $\begin{array}{l}\text { D-TAI gain is } \\
\text { higher than } \\
\text { varied } \\
\text { lectures. }\end{array}$ \\
\hline
\end{tabular}

D-TAI learning is very suitable to be implemented in science learning. This is supported by the opinion of Balim (2009), that science learning needs to implement a learning process based on the discovery of higher-order thinking (one of them is analytical thinking), questions, and problem solving. Discovery learning can improve students' analytical thinking skills. In line with the results of Wahyuni's research (2014) states that learning by using the guided discovery model assisted by the concept map provides opportunities for students to do a lot of activities, learning more interesting, and active students so that the students' analytical thinking skills taught using the guided discovery model assisted with a concept map are more high compared to students who use conventional models. The D-TAI learning model is also able to 
improve students' analytical thinking skills. In line with the results of Laksani's (2013) research, the TAI model is able to improve students' analytical thinking skills, the provision of scores and awards for the best groups in TAI syntax motivates students to study more actively in solving problems and is active in group discussion activities and presentations. The D-TAI learning model allows students to make discoveries by applying scaffolding techniques either with the teacher or other students. The teacher helps students solve problems by giving questions that lead students to construct concepts. Students work together to learn from each other and learn among group members, heterogeneous division of groups allows peer tutors to occur so that even distribution of concepts is achieved. Besides this model is also able to overcome the time allocation because teachers do not guide one by one student but in one group (Gijlers \& Jong, 2005).

Research results by Joolingen (2007) state that discovery learning models combined with collaborative methods can improve student learning outcomes and communication skills, because students exchange ideas in discussion and presentation activities. Wilke (2015) in his research stated that the discovery model combined with the model of lecture based instruction to be discovery-based instruction was able to improve student achievement, the results of the study showed that students who were taught using the discovery-based instructional model had better learning achievement than students who are taught with lecture based instruction. The positive impact seen in student attitudes is students are active in solving problems and assume that the discovery model can help students gain an understanding of the material and help develop skills that can be used in other programs.

Discovery models provide opportunities for students to do a lot of activities, more interesting learning and active students, supported by research conducted by Uslde (2013) in Kenya stating that discovery models compared to demonstration methods have better influence to increase learning retention, learning achievement, and student confidence. Psychomotor and affective learning outcomes of students taught using discovery models provide extensive opportunities for students to be creative, in Udo's research (2010) states that discovery models are able to empower students' scientific attitudes and behaviors, and have an impact on increasing learning motivation, understanding, memory, processes transfer of information, and applications in learning science (Lavine, 2005). Research conducted by Nneji (2010) states that the TAI model can improve junior high school students' learning achievement in Nigeria supported by Akdeniz \& Tarim's research (2008) which states that the TAI model compared to the STAD model has a better influence on student learning achievement.

The D-TAI learning model is able to create cognitive conflict in students, students not only work in the realm of low-thinking, but are already referring to analytical thinking. Students are able to empower the characteristics of science that produce products through scientific processes and methods based on scientific attitudes so that students are able to construct their own knowledge and be able to learn and learn through cooperative activities that are able to change the teacher centered paradigm into a student centered.

The application of the D-TAI model received positive responses from both the teacher and students. The teacher agrees that the D-TAI model is more effective in achieving learning goals, the teacher strongly agrees that the D-TAI model is more systematic, the teacher strongly agrees that the D-TAI model demands the ability of the teacher to create a conducive learning atmosphere, the teacher agrees that the D-TAI model does not require an understanding of the approach and scientific method, the teacher strongly agrees that the D-TAI model is interesting because it emphasizes the use of methods of observation and discussion. The teacher strongly agrees that activities through observation are more meaningful and help students understand the material of the human reproductive system, the teacher strongly agrees that the D-TAI model is beneficial for students in their daily lives, the teacher aims to learn DTAI more effectively in overcoming time allocation, the teacher strongly agrees that learning using the D-TAI model increases student motivation, and the teacher strongly agrees that learning using the D-TAI model trains student independence.

The results of the students' responses stated as much as $87.50 \%$ of students agreed that learning became more interesting, $100 \%$ of students agreed that group discussion made selfconfidence increase, $83.33 \%$ of students agreed the material was easier to understand, $91.66 \%$ of students agreed the workbook students are easy 
to understand, and $83.33 \%$ of students agree on the tasks in learning to practice thinking skills

\section{CONCLUSION}

The development of the D-TAI model on the material of the human reproductive system is carried out by taking into account the characteristics of the learning model namely the theoretical foundation of syntax, social systems, support systems, student roles, teacher roles, instructional impacts, and accompaniment impacts.

The results of developing the D-TAI learning model on the material of the human reproductive system are feasible to support learning on the material. The feasibility of the DTAI learning model is based on the assessment of experts, practitioners, and student responses which overall give a good category to the product development.

The D-TAI learning model can improve students' analytical thinking skills. This is indicated by the significant difference from the average analytical thinking ability of students between the D-TAI model class (XI MIA 4) and the control class (XI MIA 3).

\section{REFERENCES}

Akdeniz. F. \& Tarim, K. (2008). The effects of cooperative learning on Turkish elementary students' mathematics acbievement and attitude towards mathematics using T.A.I. and S.T.A.D. Methods. Educational Studies in Mathematics, Vol. 67, No. 1 (Jan., 2008), pp. 77-91.

Balim, Ali Gunay. (2009). The effect of Discovery Learning on Student Success and Inquiry Learning Skills. Egitim ArastirmalariEurasian Journal of Educational Research.35,1-20.

BSNP. (2013). Laporan Hasil Ujian Nasional Tahun Pelajaran 2012-2013 (software).

Dahar, Ratna Wilis. (2011). Teori - teori Belajar dan Pembelajaran. Jakarta: Erlangga.
Elder, Linda. Paul, Richard. (2007). The thinker's guide to analytical thinking, how to take thinking apart and what to look for when you do, the element of thinking and the standards they must meet. http://www.criticalthinking.org. Diakses pada tanggal 11 Januari 2015.

Fatmawati, Dwitya Nadia. (2013). Pengembangan Model Pembelajaran Experiental Learning yang Diarahkan untuk Strategi Pembelajaran Think Talk Write di Kelas XI SMA Taruna Nusantara Magelang. Tesis tidak diterbitkan. Surakar ta: PPS Universitas Sebelas Maret.

Gijlers, H., de Jong, T. (2005). The relation between prior knowledge and students' collaborative discovery learning processes. Journal of Research in Science Teaching, 42, 264-282.

Husain. R. T. (2013). Penerapan MetodeDisco

very Learning Dalam Meningkatkan Hasil Belajar Siswa Pada Mata Pelajaran Qur'an Hadits. Universitas Negeri Gorontalo. Jurnal of pedagogi

ka. Vol 4. No. 1.

Ilahi, Muhammad Takdir.(2012). Pembelajaran Discovery Strategi dan Mental Vocational Skill. Yogyakarta: Diva Press.

Jannah, S. I. (2009). Efektivitas Metode Pembelajaran Tai (Team Assisted Individualiztion) Dalam Meningkatkan Prestasi Belajar Siswa Pada Mata Pelajaran Pai. UIN Sunan Ampel Surabaya. Vol 2. No 2.

Jonassen, David H. and Hung, Woci. (2008). All Problems are not Equal:Implications for Problem-Based Learning. The Interdisclipnary Journal of Problem-Based Learning. Vol 2. No 2.

Joolingen, W. F. 2007. Coognitive Tools for Discovery Learning. International Journal of Artificial Intelligence in Education (IJAIED), 10, pp.385-397. 
Joyce, B., Weil, M., \& Calhoun, E. 2004. Models of Teaching. Boston: Pearson Education, Inc.

Kemendikbud.(2013). Materi Pelatihan Guru Implementasi Kurikulum 2013. Hand out:258363.

Laksani, Mertiara Ratih Terry. (2013). Pengaruh Model Pembelajaran Teams Assisted Individualization terhadap Kemampuan Berpikir Analitis Pada Mata Pelajaran Geografi Siswa Kelas X Public Senior High School 1 Malang. Skripsi, Jurusan Pendidikan Geografi FIS Universitas Negeri Malang.

Lavine, Robert A. (2005). Guided Discovery Learning with Videotaped Case Presentation in Neurobiology. IAMSE Volume 15: 4-7.

Listyani, E. (2011). Implementasi Metode Inquiri Dipadukan dengan Startegi Kooperatif Untuk Membangun Kemampuan Berpikir Matematis. Yogyakarta. Universitas Sebelas Maret. Vol 2. No 1.

Mahmudah, Laili. (2014). Pembelajaran Fisika Menggunakan Metode Pictorial Riddle Dan Problem Solving Ditinjau Dari Kemampuan Berpikir Kritis Dan Kemampuan Analisis. Universitas Sebelas Maret. Vol 3. No 2

Montaku.S. (2011). Result of Analytical Thinking Skills Training Trought Student in System Analysis and Design.

Nneji, Awofala. 2010. Effect of Framing and Team Assisted Individualized' Instructional Strategies on Students' Achievement in Mathematics.Journal of Science Teachers' A ssociation of Nigeria. Vol 2. No 3. Page 23-28.
Rose, Colin., and Malcolm J. Nicholl. 2002. Accelerated Learning for the 21st Century. Bandung: Nuansa.

Schunk, Dale. H. (2012).Learning TheoriesA Per pesctive Education(Terjemahan). Yogyakarta: Pustaka Media.

Silberman, Mel. (2001). 101 StrategiPembelajaran Aktif. Yogyakarta: Pustaka pelajar.

Siregar. E. Dan Nara, H, (2010). Teori Belajar dan Pembelajaran. Bogor: Gahlia Indonesia.

Slameto. (2003). Belajar dan Faktor-faktor yang Mempengarubinya. Jakarta: PT. Rineka Cipta.

Slavin, Robert E, (2009).Cooperative Learning: Teori, Riset dan Praktik, Bandung: Nusa Media.

Trianto. (2007). Model - Model Pembelajaran Inovatif Berorientasi Konstruktivistik. Jakarta: Prestasi Pustaka Publisher.

Udo, Mfon Effiong. (2010). Department of Science Education, University of Uyo, Uyo Cross River State, Nigeria. An International MultiDisciplinary Joumal, Ethiopia. Vol. 4 (4), Serial No. 16. Pp. 389-398.

UNESCO. (2013). Revisiting Learning: The Treasure Within Assessing The Influence of The 1996 Delors Report. United Nations Educational, Scientific and Cultural Organization.

Uslde. (2013). Effect Of Discovery Method On Secondary School Student's Acbievement In Physics In Kenya. Asian Journal Of Social Sciences \& Humanities. Vol 2. No 3.

Wahyuni, T. (2014). Perbedaan Model Guided Discovery Learning Berbantu Concept Map Dengan Model Konvensional Terbadap Kemampuan Berpikir Analitis Siswa Kelas Xi 
Ipa Public Senior High School 5 Surakarta. Universitas Sebelas Maret.

Wilke, R. Russel. dan Straits, W. (2015). The Effect Of Discovery Learning In A Lower-Division Biology Course. Advances in Physiol Edu. Vol 25. No 2. Page 62-69. 